\title{
Study of Bacteriological Profile in Urinary Tract Infection in Pregnant Women
}

\author{
K. Bhaskaran, G. Hemalatha* and K. Sethumadhavan \\ Department of Microbiology, Aarupadai Veedu Medical College \& Hospital, \\ Puducherry, India
}

\begin{tabular}{l} 
Ke y w o r d s \\
$\begin{array}{l}\text { UTI in pregnancy, E. coli, } \\
\text { Asymptomatic } \\
\text { bacteriuria, Antimicrobial } \\
\text { resistance }\end{array}$ \\
\hline Article Info \\
$\begin{array}{l}\text { Accepted: } \\
\text { 06 September } 2018 \\
\text { Available Online: } \\
\text { 10 October } 2018\end{array}$ \\
\hline
\end{tabular}

\section{A B S T R A C T}

Urinary tract infection (UTI) is the most common human bacterial infection in the community as well as in hospital settings (Vijaya Swetha et al., 2014). Urinary tract infection during pregnancy may cause complications such as pyelonephritis, hypertensive disease of pregnancy, anaemia, chronic renal failure, premature delivery and foetal mortality (Moyo et al., 2010). Early diagnosis and treatment of UTI has shown marked improvement in pregnancy outcome as well as reduction of the incidence of acute pyelonephritis, highlighting the need to screen all women in pregnancy irrespective of symptoms. This was a prospective study, conducted in 60 pregnant women attending Department of Obstetrics and Gynaecology OP/IP. Among 60 samples, 6(10\%) samples yielded significant bacterial growth and 54 samples showed insignificant growth. E. coli was isolated as predominant pathogen. These $E$. coli isolates were resistant most commonly to cefuroxime (98\%) followed by ampicillin (96\%) and ciprofloxacin (54\%) and were most sensitive to nitrofurantoin (83.3\%) followed by Amikacin (66.6\%), cotrimoxazole $(68 \%)$.

\section{Introduction}

Urinary Tract Infection (UTI) is defined as the microbial invasion of any of the tissue of the urinary tract extending from the renal cortex to the urethral meatus. Urine formed in the kidney is a sterile fluid that serves as a good culture medium for proliferation of bacteria (Okonko et al., 2009). Women are at greater risk for UTI than men, partly because of the relatively short straight urethra, retrograde ascent of bacteria from the perineum, changes in normal vaginal flora. Simple hygiene habits, including voiding before and after sexual intercourse and wiping from anterior to posterior, tend to decrease the risk of UTI. Anatomically, UTI is been classified into Lower Urinary Tract Infection involving the bladder and urethra and Upper Urinary Tract Infection involving the kidney, pelvis and ureter. UTI is reported among $20 \%$ of the pregnant women and it is the most common cause of admission in obstetrical wards (Lawani ebidor et al., 2015).

After anaemia, UTI is the second common complication in pregnant women, which if not controlled well, can adversely affect the health of infants or the pregnant mothers. In pregnancy, UTI is classified into two 
categories of symptomatic and asymptomatic. The involvement of the lower urinary tract, leading to asymptomatic bacteriuria, is the most common cause of UTI during pregnancy. The involvement of the upper urinary tract can lead to symptomatic bacteriuria and is characterized by acute pyelonephritis.

Based on performed researches, the prevalence of symptomatic Urinary Tract Infection in pregnant women has been $17.9 \%$ and in asymptomatic form 13\%. If asymptomatic infection is not treated, it leads to some clinical manifestations in mother and newborn (Marziyeh Amiri et al., 2015).

Increased age, number of childbirths, number of intercourses per week, diabetes, recessive sickle cell anaemia, previous history of UTI, immunodeficiency and urinary tract abnormalities can increase the risk of UTI in pregnant women. Bacterial organisms, which cause this disease, include Escherichia coli, Klebsiella pneumonia, Proteus, Acinetobacter, Staphylococcus, Streptococcus Group B and Pseudomonas aeruginosa (Wanyoike Gichuhi et al., 2015).

The incidence of UTI increases in pregnancy with increasing gestation months, though the probability of UTI is initiated by the sixth week of pregnancy. This probability peaks at 22 - 24 weeks of gestational age. The reasons for increased probability of infection in pregnant women are probably increased bladder volume and its expansion and expanded ureter. Anatomical and physiological changes occurring during pregnancy alter the course of bacteriuria and make pregnant women more susceptible to UTI complications such as pyelonephritis.

Early diagnosis and treatment of UTI has shown marked improvement in pregnancy outcome as well as reduction of the incidence of acute pyelonephritis, highlighting the need to screen all women in pregnancy irrespective of symptoms. In view of the potential importance of bacteriuria in pregnancy, the present study was undertaken to set gold standard method of urine culture and sensitivity as effective screening test for UTI in pregnancy.

\section{Materials and Methods}

This was a prospective study, conducted in 600 pregnant women attending Department of Obstetrics and Gynaecology OP/IP, for a period of six months, after obtaining clearance from Institutional research committee.

Informed consent was taken from the patients. Patients not giving consent to participate and on antibiotics since 2 weeks were not included in this study. Only one sample from one patient was included in this study.

Clean catch midstream urine samples were collected in sterile containers. Wet mount examination after centrifuging the sample was done to look for pus cells, RBCs, casts, microorganisms, crystals if any and inoculated within 30 minutes on to nutrient agar, blood agar and Mac Conkey agar with sterile precautions; incubated in aerobic environment at $37^{\circ} \mathrm{C}$ for 24 hours. Growth of one type of organism of $>10^{5}$ colony forming units, in more than one medium was considered as significant bacteriuria. The isolates were then identified based on colony morphology and biochemical reactions (Cowan and Steel, 1974). Mueller- Hinton agar was used to perform antimicrobial susceptibility testing for all the isolates (NCCLS, 1999). The zone of inhibition was measured and interpreted according to CLSI guidelines 2016. Antimicrobial drug susceptibility testing was done on all pathogenic bacteria isolated.

Patients with symptoms of UTI, >50 pus cells per high power field with or without RBCs in 
wet mount examination of urine sample and single organism isolated with significant growth is categorised as symptomatic bacteriuria. Patients without symptoms of UTI, $<10$ pus cells per high power field with or without RBCs in wet mount examination of urine sample and single organism isolated with significant growth is categorised as asymptomatic bacteriuria.

\section{Ethical consideration}

There was no risk to the participants as there were no invasive procedures done. Participants whose test results showed any growth of microbes benefitted by being treated as per the culture and sensitivity results. No adverse reactions to the drugs were expected as these were the drugs routinely used in the department.

\section{Results and Discussion}

A total of 600 urine samples were received from pregnant women.

Among 600 samples, 60(10\%) samples yielded bacterial growth.6 samples showed symptomatic bacteriuria and 54samples showed asymptomatic bacteriuria (Table 1). E . coli was isolated as predominant pathogen (Table 2).

These Escherichia coli (E. coli) isolates showed resistance most commonly to cefuroxime $(98 \%)$ followed by ampicillin (96\%) and ciprofloxacin (54\%). It was most sensitive to imipenem (96\%), piperacillin
(92\%), nitrofurantoin (85\%) followed by amikacin and cotrimoxazole (69\%) (Table 3).

The demographic variables such as age-wise distribution, educational status, gestational age, gravida status of the pregnant women are related to symptomatic and asymptomatic bacteriuria.

\section{Statistical analysis}

Statistical analysis was performed by the chisquare test. A p-value $<0.001$ was taken as significant.

\section{Age distribution}

From Table 4 the study reports urine samples of 60 pregnant women with UTI fall within the age groups 21-35 years of which 55\% were in 26-30 years age group. There is an increased presentation of asymptomatic bacteriuria in 26-30 yrs age group and it is statistically significant with $\mathrm{p}$-value $<0.0001$ This is in agreement with studies in Kenya (Wanyoike Gichuhi et al., 2015), Nigeria (Lawani ebidor u et al., 2015), Pondicherry (Valentina and Srirangaraj, 2016) and Iran (Marziyeh Amiri et al., 2015).

\section{Socioeconomic status}

From Table 5 socioeconomic status of 60 pregnant women with UTI was found to be middle class and high class of which middle class were found to be predominant of $73.33 \%$. This is in agreement with studies in Kenya (Wanyoike Gichuhi et al., 2015).

Table.1 Patients with Bacteriuria

\begin{tabular}{|l|l|l|l|}
$\begin{array}{l}\text { Total no. of } \\
\text { samples }\end{array}$ & $\begin{array}{l}\text { Significant growth } \\
\text { in culture }\end{array}$ & $\begin{array}{l}\text { Symptomatic } \\
\text { bacteriuria }\end{array}$ & $\begin{array}{l}\text { Asymptomatic } \\
\text { bacteriuria }\end{array}$ \\
\hline 600 & 60 & 6 & 54
\end{tabular}


Table.2 Pathogenic flora isolated

\begin{tabular}{|l|l|l|}
\hline Organism isolated & No. of samples & \% of samples \\
\hline Escherichia coli. & 26 & 43 \\
\hline Klebsiella sp.. & 13 & 22 \\
\hline Proteus sp.. & 7 & 12 \\
\hline Enterobacter sp.. & 7 & 12 \\
\hline Staphylococcus aureus & 4 & 6 \\
\hline Candida albicans & 3 & 5 \\
\hline Total & 60 & 100 \\
\hline
\end{tabular}

Table.3 Antibiotic sensitivity pattern, percentage in parantheses

\begin{tabular}{|c|c|c|c|c|c|c|c|c|c|c|}
\hline \multirow[t]{2}{*}{ Antibiotics } & \multicolumn{2}{|c|}{ E. coli (26) } & \multicolumn{2}{|c|}{$\begin{array}{l}\text { Klebsiella } \\
\text { sp..(13) }\end{array}$} & \multicolumn{2}{|c|}{$\begin{array}{l}\text { Proteus } \\
\text { sp..(7) }\end{array}$} & \multicolumn{2}{|c|}{\begin{tabular}{|l} 
Entero \\
bacter sp..(7)
\end{tabular}} & \multicolumn{2}{|c|}{$\begin{array}{l}\text { Staph. } \\
\text { aureus (4) }\end{array}$} \\
\hline & $\mathrm{S}$ & $\mathrm{R}$ & $\mathrm{S}$ & $\mathrm{R}$ & $\mathrm{S}$ & $\mathrm{R}$ & $\mathrm{S}$ & $\mathrm{R}$ & $\mathrm{S}$ & $\mathrm{R}$ \\
\hline Amikacin & $18(69)$ & $8(31)$ & $10(77)$ & $3(23)$ & $3(43)$ & $4(57)$ & $1(14)$ & $6(86)$ & & \\
\hline Amoxyclav & $17(65)$ & $9(35)$ & $4(31)$ & $9(69)$ & $2(28)$ & $5(72)$ & $2(28)$ & $5(72)$ & (25) & (75) \\
\hline Ampicillin & 1(4) & $25(96)$ & $1(8)$ & $12(92)$ & $1(14)$ & $6(86)$ & $3(43)$ & $4(57)$ & (0) & (100) \\
\hline Gentamicin & $15(57)$ & $11(43)$ & $10(77)$ & $3(23)$ & $5(71)$ & 2(29) & $6(86)$ & $1(14)$ & & \\
\hline Ciprofloxacin & $12(46)$ & $14(54)$ & $11(85)$ & $2(15)$ & $6(86)$ & $1(14)$ & $7(100)$ & $0(0)$ & $(50)$ & $(50)$ \\
\hline Norfloxacin & $17(65)$ & $9(35)$ & $11(85)$ & $2(15)$ & $6(86)$ & $1(14)$ & $6(86)$ & $1(14)$ & (50) & $(50)$ \\
\hline Nitrofurantoin & $22(85)$ & $4(15)$ & $9(69)$ & $4(31)$ & $7(100)$ & $0(0)$ & $6(86)$ & $1(14)$ & (25) & (75) \\
\hline Cotrimoxazole & $18(69)$ & & $7(54)$ & & $5(71)$ & $2(29)$ & $6(86)$ & $1(14)$ & (25) & (75) \\
\hline Imipenem & $25(96)$ & 1(4) & 12(92) & $1(8)$ & $7(100)$ & $0(0)$ & $7(100)$ & $0(0)$ & & \\
\hline Piperacillin & $24(92)$ & $2(8)$ & $11(85)$ & $2(15)$ & $7(100)$ & $0(0)$ & $7(100)$ & $0(0)$ & & \\
\hline Cefuroxime & 1(4) & $25(96)$ & $11(85)$ & $2(15)$ & $6(86)$ & $1(14)$ & & & & \\
\hline Ceftriaxone & $4(15)$ & $22(85)$ & $12(92)$ & $1(8)$ & $6(86)$ & $1(14)$ & $7(100)$ & $0(0)$ & (75) & (25) \\
\hline $\begin{array}{l}\text { Chloram } \\
\text { phenicol } \\
\end{array}$ & $18(69)$ & $8(31)$ & $10(77)$ & $3(33)$ & $4(30)$ & $3(70)$ & & & (0) & (100) \\
\hline Erythromycin & & & & & & & & & (0) & (100) \\
\hline Cefoxitin & & & & & & & & & (50) & $(50)$ \\
\hline
\end{tabular}

Table4 Age-wise distribution of pregnant women with bacteriuria

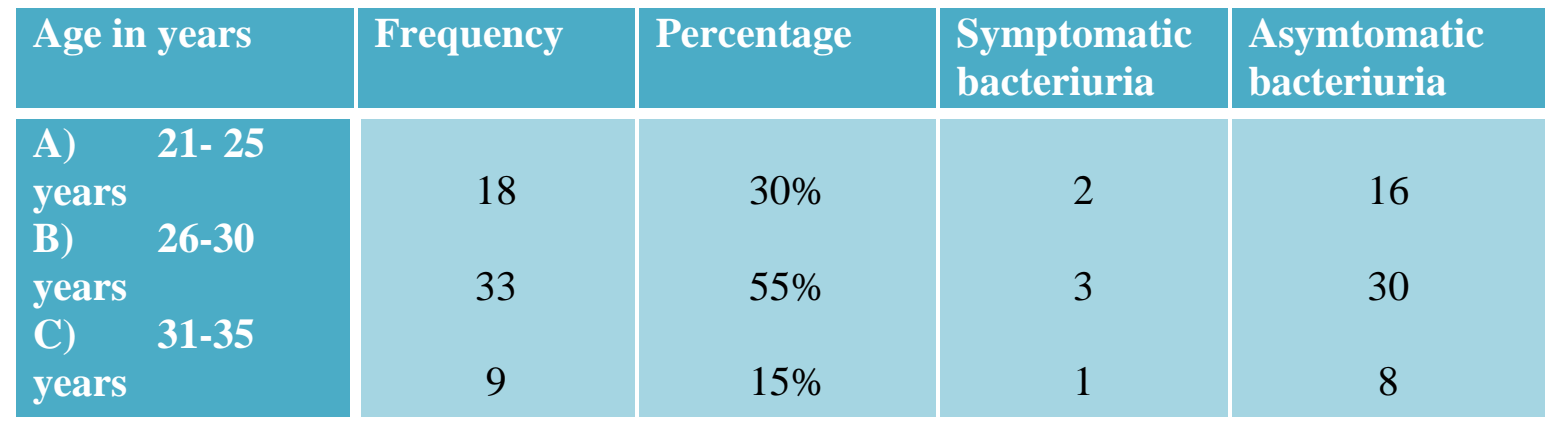


Table.5 Socioeconomic status of pregnant women with bacteriuria

\begin{tabular}{|c|c|c|c|c|}
\hline $\begin{array}{c}\text { Socioeconomic } \\
\text { status }\end{array}$ & Frequency & Percentage & $\begin{array}{l}\text { Symptomatic } \\
\text { bacteriuria }\end{array}$ & $\begin{array}{l}\text { Asymtomatic } \\
\text { bacteriuria }\end{array}$ \\
\hline High class & 44 & $73.33 \%$ & - & - \\
\hline Middle class & & & 2 & 42 \\
\hline Low class & 16 & $26.67 \%$ & 4 & 14 \\
\hline
\end{tabular}

Table.6 Educational status of pregnant women with bacteriuria

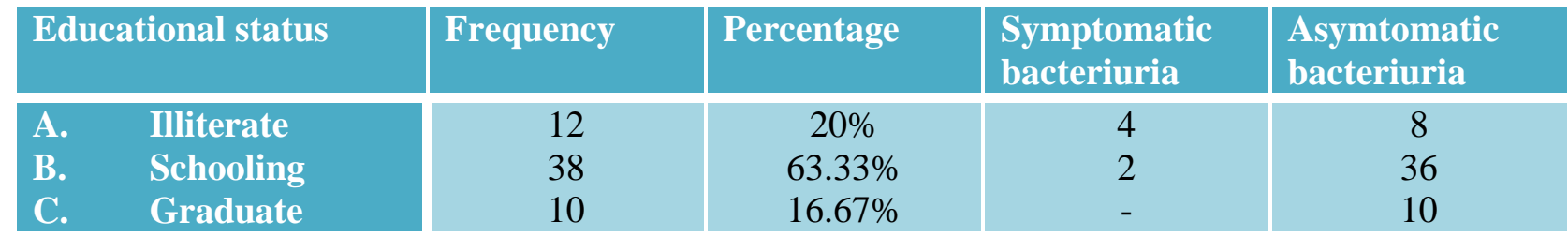

Table.7 Gestational age of pregnant women with bacteriuria

\begin{tabular}{|c|c|c|c|c|c|}
\hline & rimester & Frequency & Percentage & $\begin{array}{l}\text { Symptomatic } \\
\text { bacteriuria }\end{array}$ & $\begin{array}{l}\text { Asymtomatic } \\
\text { bacteriuria }\end{array}$ \\
\hline A. & First & 16 & $26.67 \%$ & 2 & 14 \\
\hline B. & Second & 6 & $10 \%$ & 1 & 5 \\
\hline C. & Third & 38 & $63.33 \%$ & 3 & 35 \\
\hline
\end{tabular}

Table.8 Gravida status of pregnant women with bacteriuria

\begin{tabular}{|c|c|c|c|c|}
\hline Gravida & Frequency & Percentage & $\begin{array}{l}\text { Symptomatic } \\
\text { bacteriuria }\end{array}$ & $\begin{array}{l}\text { Asymtomatic } \\
\text { bacteriuria }\end{array}$ \\
\hline Primi & 26 & $43.33 \%$ & 2 & 24 \\
\hline Multi & 34 & $56.67 \%$ & 4 & 30 \\
\hline
\end{tabular}

\section{Education status}

From Table 6 based on educational status, pregnant women with UTI were grouped as illiterate, schooling and graduate and found that $63.33 \%$ have done their schooling. This was in agreement with studies in Kenya (Wanyoike Gichuhi et al., 2015).

\section{Gestational age}

From Table 7 gestational age of 60 pregnant women was grouped on trimesters of which third trimester was found to the greater percentage as to $63.33 \%$. This was in agreement with studies in Nigeria (Lawani ebidor u et al., 2015). About 35 women in the third trimester with UTI had asymptomatic bacteriuria which is statistically significant with p-value $<0.0001$.

\section{Gravida status}

From Table 8 gravida status of 60 pregnant women is known and $56.67 \%$ were found to be multi gravida. This was in agreement with studies in Kenya (Wanyoike Gichuhi et al., 2015) and Iran (Marziyeh Amiri et al., 2015).

There are many published studies on UTI in pregnancy globally. Its importance is to deem a geographical bacterial flora pattern from time to time. The knowledge about the antimicrobial resistance patterns in the pathogens is crucial for the treating physicians. 
Hence it helps physicians to start on empirical treatment in pregnancy at the earliest. UTI in pregnancy is one of the preventable causes of feto-maternal complications. Appropriate screening and treatment of UTI in pregnancy has to be made mandatory worldwide.

\section{Acknowledgements}

Thankful to the department of microbiology, Aarupadai Veedu Medical College \& Hospital.

\section{References}

Cowan ST, Steel KJ. Manual for the identification of medical bacteria. $2^{\text {nd }}$ edition. Cambridge: Cambridge University Press; 1974.

Latika J Shah, Geeta M Vaghela, Hetvi Mahida, Urinary tract infection: bacteriological profile and its antibiotic susceptibility in western India, national journal of medical research.

Lawani ebidor u, AladeTolulope and Oyelaran Deborah, Urinary Tract Infection amongst Pregnant Women in Amassoma, Southern Nigeria, African Journal of Microbiology Research, Vol-9(6), 11 February 2015, pp.355-359.

Marziyeh Amiri et al., Prevalence of Urinary Tract Infection among pregnant women and its complications in their newborns during the birth in the hospitals of Dezful City, Iran. Iran Red Crescent Med Journal, 17(8), August (2015).

National Committee for Clinical Laboratory Standards. Performance Standards of Antimicrobial Susceptibility Testing. Ninth International Supplement. 1999: M100-S9.

Nileshshyamchavan, Madhurendrasingh Rajput et al., Bacteriological Profile of Urinary
Tract Infection in Female Patient attending Tertiary Care Hospital, Indore, India, International Journal of Current Microbiology and Applied Sciences, 3(7)(2014): 847-852.

Okonko, I.O., C.H. Obiogbolu et al., Incidence of Urinary Tract Infection among Pregnant Women in Akwa Metropolis South Eastern Nigeria, Scientific Research and Essay, vol-4(8), August 2009, pp.820-824.

Sabrina j. Moyo, said aboud, mabula kasub and samuel Y. Maselle, Bacterial isolates and drug susceptibility patterns of urinary tract infection among pregnant women at Muhimbili National Hospital in Tanzania, Tanzania Journal of Health Research, Volume 12, Number 4, October 2010.

Valentina, Y., and S. Srirangaraj, Pregnancy associated Urinary Tract Infection: Prevalence and Screening, International journal of current microbiology and applied science, Volume 5 Number 1(2016) pp. 452-460.

Vijaya Swetha, V., U. Sreenivasa Rao, P. Hema Prakash and S. Subbarayudu, Aerobic bacteriological profile of urinary tract infections in a tertiary care hospital, International journal of current microbiology and applied science, ISSN: 2319-7706 Volume 3 Number 3 (2014) pp. 120-125.

Wanyoike Gichuhi, J., Willy Fred Nabbugodi and N.W. Mugo, Prevalence of Urinary Tract Infection, Microbiai Aetiology, and Antibiotics Sensitivity Pattern among antenatal women presenting with Lower Abdominal Pain at Kenyatta National Hospital, Nairobi, Kenya. The Open Access Journal of Science and Technology, vol-3 (2015).

\section{How to cite this article:}

Bhaskaran, K., G. Hemalatha and Sethumadhavan, K. 2018. Study of Bacteriological Profile in Urinary Tract Infection in Pregnant Women. Int.J.Curr.Microbiol.App.Sci. 7(10): 873-878. doi: https://doi.org/10.20546/ijcmas.2018.710.096 